\title{
Menengiç, Işgın ve Çiriş Otu'nda Antioksidan Aktivitenin Araştırılması
}

\author{
Mehmet ÖZYURT ${ }^{\stackrel{8}{ }}$, Hatice KOPAR², Süheyla ÖZYURT², İlter DEMIRHAN4, Ergül BELGE KURUTAŞ ${ }^{5}$ \\ 1,2,3,5 Kahramanmaraş Sütçü İmam Üniversitesi Tıp Fakültesi, Tibbi Biyokimya Anabilim Dalı, Kahramanmaraş / Türkiye, ${ }^{4}$ Harran \\ Üniversitesi, Sağlık Hizmetleri Meslek Yüksekokulu, Elektronik ve Otomasyon Anabilim Dalı, Şanlıurfa / Türkiye \\ ${ }^{1}$ https://orcid.org/0000-0002-2129-1236, ${ }^{2}$ https://orcid.org/0000-0002-5038-4781, ${ }^{3}$ https://orcid.org/0000-0003-1413-6585, \\ ${ }^{4}$ https://orcid.org/0000-0003-0054-7893, ${ }^{5} \mathrm{https}: / / o r c i d . o r g / 0000-0002-6653-4801$ \\ $\bowtie:$ mehmetozyurtt@gmail.com
}

\begin{abstract}
ÖZET
Menengiç (Pistacia terebinthus L.), Işgın (Rheum ribes L.) ve Çiriş Otu (Asphodelus aestivus) tüm dünyada yaygın olarak bulunur ve genellikle taze olarak tüketilir. Bu çalışmada, gövde ve yaprakları seçilen üç bitkinin antioksidan aktivitelerinin incelenmesi amaçlandı. Menengiç, ışgın ve çiriş otu Kahramanmaraş bölgesinde farklı marketlerden alındı. Seçilen bitkilerin gövde ve yapraklarında antioksidan enzimler olarak superoksit dismutaz (SOD) ve katalaz (CAT) aktiviteleri ile oksidatif stresin göstergesi olarak olarak malondialdehit (MDA) düzeyi spektrofotometrik olarak ölçüldü. Menengiç, ışgın ve çiriş otu 'nun SOD ve CAT aktiviteleri karşılaştırıldığında; en yüksek CAT aktivitesi ışgın'da ölçülürken, çiriş otu'nda ise en düşük bulundu $(p<0.05)$. Ayrıca SOD aktivitesi en yüksek ışgın'da iken, en düşük SOD aktivitesi menengiç'te bulundu ( $p$ <0.05). MDA seviyeleri ışgın'da en yüksek iken, en düşük MDA düzeyleri çiriş otu'nda bulundu $(\mathrm{p}<0.05)$. Bu sonuçlar göstermiştir ki, çalışılan bitkilerin önemli antioksidan aktivitelere sahip olması; bitkilerin sahip olduğu metabolik aktivitelerinden ve fitokimyasal içeriklerinden kaynaklanabilir.
\end{abstract}

\section{Investigation of Antioxidant Activity In Menengiç, Işgın and Çiriş Otu}

\begin{abstract}
Menengiç (Pistacia terebinthus L.), Işgın (Rheum ribes L.) and Çiriş otu (Asphodelus aestivus) are widely available worldwide and are generally consumed as fresh. In this study, it was aimed to examine the antioxidant activities stem and leaves of three plants. Menengiç, ışgın and çiriş otu were purchased from different markets in the Kahramanmaraş region. Superoxide dismutase (SOD) and catalase (CAT) activities as antioxidant enzymes and malondialdehyde (MDA) level as an indicator of oxidative stress were spectrophotometrically determined in referred plant parts. When the SOD and CAT activities of menengiç, ışıı and çiriş otu seed were compared; While the highest CAT activity was measured in ışgın, çiriş otu sustained the lowest ( $p$ $<0.05)$. In addition, while SOD activity was the highest in ısgın, the lowest SOD activity was found in menengiç $(p<0.05)$. MDA levels were highest at ışgın, while the lowest MDA levels were found at çiriş otu $(p<0.05)$. These results show that the plants studied have important antioxidant activities caused by the metabolic activities and phytochemical contents of plants.
\end{abstract}

Araştırma Makalesi
$\begin{array}{ll}\text { Makale Tarihçesi } \\ \text { Geliş Tarihi } \quad: 02.11 .2020 \\ \text { Kabul Tarihi } \quad: 22.12 .2020\end{array}$

Anahtar Kelimeler
Asphodelus aestivus
Pistacia terebinthus
Rheum ribes

\section{Research Article}

$\begin{array}{ll}\text { Article History } & \\ \text { Received } & : 02.11 .2020 \\ \text { Accepted } & : 22.12 .2020\end{array}$

\section{Keywords}

Asphodelus aestivus

Pistacia terebinthus

Rheum ribes

Atıf İçin: Özyurt M, Kopar H, Özyurt S, Demirhan İ, Belge Kurutaş E 2021. Menengiç, Işgın ve Çiriş Otu'nda Antioksidan Aktivitenin Araştırılması. KSÜ Tarım ve Doğa Derg 24 (4): 733-737. DOI: 10.18016/ksutarimdoga.vi.819974.

To Cite: Özyurt M, Kopar H, Özyurt S, Demirhan İ, Belge Kurutaş E 2021. Investigation of Antioxidant Activity In Menengiç, Işgın and Çiriş Otu. KSU J. Agric Nat 24 (4): 733-737. DOI: 10.18016/ksutarimdoga.vi.819974.

\section{Gİiș}

Çeşitli insan hastalıklarını tedavi etmek için bitkilerin kullanımı uzun bir tarihe sahiptir. Yaprak, gövde, ağaç kabuğu, kök gibi bitkilerin çeşitli kısımları semptomları önlemek, anormallikleri normale döndürmek için kullanılır. Bazı bitkilerin antioksidan aktiviteleri ile ilgili bilimsel çalışmalar olmasına rağmen, sinırlıdır. 
Serbest oksijen radikallerinin neden oldukları muhtemel zararlara çok sayıda hücre koruyucu enzimler yardımıyla karşı koyulur ve meydana gelen radikal hasar antioksidan maddeler ile sınırlandırılmaya çalışılır. Vücudumuzda bulunan serbest radikaller ve antioksidan maddeler arasındaki ilişki sürekli denge durumundadır. Antioksidanlar hücre içerisinde oksijen oluşan yerlerde oksijen ara metabolitlerini azaltmak için enzimatik olarak çalışmaktadırlar. Antioksidan savunmada sisteminde birincil olarak enzimatik antioksidanlar etkilidirler. Bunlar süperoksit dismutaz, katalaz, glutatyon peroksidaz ve glutatyon redüktaz gibi enzimlerdir (Delaber ve ark., 1987). Serbest radikallere maruz kalan insan vücudunun, oluşan oksidatif stresi ortadan kaldırabilmek için en önemli silahı olan antioksidanlar, hücre hasarını engelleyebilmeleri açısından da oldukça önemli maddelerdir.

Antioksidanlar hem vücut tarafından sentezlenebilir hem de diyet ile dışarıdan da alınabilirler. Canlı organizmalarda antioksidan sistemler, metabolizmada üretilen (endojen) ve dışarıdan diyet ile alınanlar (ekzojen) olmak üzere iki gruba ayrılır. Endojen antioksidan sistemi, antioksidan enzimler, hasarlı molekülleri uzaklaştırıcı proteazlar ve fosfolipaz gibi enzimler, yeni bileşikleri sentezleyen sistemler, glutatyon, ürik asit ve çeşitli metal bağlayıcılarından oluşmaktadır. Tüm antioksidanlar serbest radikal süpürücü olarak görev yaparlar. Antioksidanların, kanser, kalp hastalıkları, inflamatuar ve diyabet gibi birçok hastalığın başlamasına sebep olan oksidatif stres ve serbest radikallerin hasarlarına karşı koruma görevi üstelendiği bilinmektedir. Bu özelliklerinden dolayı, savunma sisteminin etkisini artırmak suretiyle hastalık riskini de azaltmış olurlar (Bursal, 2009; Sen ve ark., 2010; Shinde ve ark., 2012).

$P$. terebinthus, Anacardiaceae (Sakızağacigiller) familyasına ait bir türdür. $P$. terebinthus çalı formunda, küçük ağaç yapısına sahip olup, yaprağını döken bir türdür. Melengiç / Menengiç olarak bilinmekte olup, Türkiye'de en yaygin türlerden birisidir. Uçucu yağ içeriği sebebiyle ekonomik anlamda önem arz eden bitkinin Akdeniz Bölgesi, Güney Doğu Anadolu Bölgesi ve Ege kıyılarında yayılış gösterdiği bilinmektedir. Alternatif tıbbi bitki ve gida olarak olarak kullanılmaktadır (Baytop, 1984).

Polygonaceae familyasının bir üyesi olan ve çok yıllık otsu bir yapıya sahip olan Işgın bitkisi, İran-Turan fitocoğrafik bölgesinin bir elamanıdır. Türkiye ile birlikte ve Türkiye'ye komşu olan bazı ülkelerde yetişmektedir (Davis, 1967). Sürgünleri $40 \mathrm{~cm}$ yüksekliğe kadar büyüyebilir ve bu sürgünler tabanda yapraklı, üstte ise yapraksız bir yapıya sahiptir. Genellikle kayalık ve çakıl yapıya sahip olan yamaçlarda yetiştiği bilinmektedir. Halk arasında bitkinin sürgünleri ve yaprak sapı taze olarak tüketilmektedir. Işgın bitkisinin gövdesi ve yaprakları oldukça ekşi bir lezzete sahip olmakla birlikte, mideyi kuvvetlendiren, kusmayı önleyen ve kabız etkiye sahip olan faydalarının olduğu belirtilmektedir (Baytop, 1984).

Çiriş otu Asphodelaceae familyasına ait bir türdür. Yaprakları kılıç şeklinde olan çiriş otunun boyu 50-150 $\mathrm{cm}$ civarında, $3 \mathrm{~cm}$ eninde bir yapiya sahiptir. Genellikle nisan ile mayıs aylarında çiçek açtığı bilinmektedir. Bezelye şekilli yeşil meyvelere sahip olan çiriş otu bütün yil boyunca yeşil bir bitkidir. Halk arasında hemoroid, romatizma, adet söktürücü, idrar söktürücü, saçkıran, süt artırıcı, egzama, sivilce ve çıbanların tedavisinde ilaç olarak kullanıldığ belirtilmektedir. $\mathrm{Bu}$ bitkinin beyaz kan hücrelerini (WBC) artırdığı ve bu özelliğinden dolayı da savunma sistemi için önemli bir etkiye sahip olduğu rapor edilmektedir (Baytop, 1984; 1997; Karataş ve ark., 2011).

$\mathrm{Bu}$ çalışmada kullanılan bitkilerinin halk tarafindan hem gida maddesi olarak hem de çeşitli hastalıkların tedavisinde kullanıldığı bilinmektedir. Günümüzde birçok ilacın hammaddesini tıbbi ve aromatik bitkilerin sentezlemiş olduğu bileşikler oluşturmaktadır. Literatür taramalarında, bu üç bitkiyle ilgili antioksidan aktiviteyi inceleyen in vitro bir çalışmaya rastlanılmamıştır. Bu sebeple yapılan çalışmada bu bitkilerinin antioksidan aktivitelerinin incelenmesi araştırıldı.

\section{MATERYAL ve METOD}

Menengiç, çiriş otu ve ışgın Kahramanmaraş bölgesinde farklı marketlerden alındı. Biyokimyasal analizler için laboratuvara gönderildi.

\section{Biyokimyasal Analizler}

Biyokimyasal analiz için bitki ekstresinin hazırlanması

$\mathrm{Bu}$ bitkilerin gövde ve yapraklarından \%1.15 potasyum klor ile homojenize edilerek ekstreler hazırlandı. Hazırlanan yaprak ekstrelerinde antioksidan enzim düzeyleri ve MDA düzeyleri ölçüldü.

\section{Antioksidan Aktivitenin Saptanması}

CAT aktivitesi ekstrede Beutler yöntemiyle saptanmıştır (Beutler, 1984). Reaksiyon karışımı 1 M Tris-HCI pH 8.0 tampon, $10 \mathrm{mM}$ hidrojen peroksit, belirli miktarda saf su ve enzim içeren ekstreden oluşmaktadır. Tepkime, $37{ }^{\circ} \mathrm{C}$ 'de enzim tarafından yıkılan hidrojen peroksit'in $230 \mathrm{~nm}$ dalga boyunda ışık yolu $1 \mathrm{~cm}$ olan kuvars küvetlerde 10 dakika süreyle her 5 dakikadaki absorbans değişimi izlenerek gerçekleştirilmiştir. SOD aktivitesi Fridovich yöntemiyle saptanmıştır (Fridovich, 1995). SOD aktivite tayini için ekstre 1:65 oranında 0.01 M Fosfat tampon pH 7.0 ile dilue edilmiş, bu dilüsyonda aktivite 
tayini yapılmıştır. Reaksiyon karışımı ekstre, ksantin ve INT (p-iyodonitrotetrazoliyum viyolet) içeren miks substrat ve ksantin oksidazdan oluşur. Kör de tıpkı numune gibi hazırlanır fakat örnek yerine fosfat tamponu konmuştur. Tepkime, $37^{\circ} \mathrm{C}$ 'de 1 şık yolu $1 \mathrm{~cm}$ olan kuvars küvetlerde numunenin $505 \mathrm{~nm}$ dalga boyunda havaya karşı ilk 30 saniyedeki başlangıç absorbansları (A1) okunarak gerçekleştirilmiştir. Aynı anda kronometre çalıştırılarak 3 dakika sonra son absorbansları (A2) okunmuş ve değerler standart eğriden değerlendirilmiştir. MDA düzeyi ekstrede Ohkawa yöntemiyle saptanmıştır (Ohkawa, 1979). Aerobik şartlarda pH 3.4'de tiyobarbitürik asit (TBA) ile numunenin inkübasyonu sonucu oluşan lipid peroksidasyonun sekonder ürünü olan MDA'nın TBA ile pembe renkli kompleks oluşturma esasına dayanır. Oluşan renk şiddeti ortamdaki MDA konsantrasyonu ile doğru orantılıdır; 532 nm'de spektrofotometrik olarak değerlendirilmiştir. Protein düzeyi ekstrede Lowry metoduyla ölçülmüştür (Lowry, 1951). Sığır bovin serum albumin standart olarak kullanılmıştır.

\section{İstatistik Analizler}

İstatistiksel değerlendirmeler SPSS 22.0 paket programında yapıldı. Bitkilerin birbirleriyle karşılaştırılmalarında Mann Whitney $U$ testi ve varyans analizi kullanıldı. İstatistiksel anlamlılık olarak $\mathrm{p}<0.05$ düzeyi alındı.

\section{BULGULAR}

En yüksek CAT aktivitesi Işgın'da ölçülürken, Çiriş Otu'nda ise en düşük bulundu $(p<0.05)$. Ayrıca SOD aktivitesi en yüksek Işgın'da bulunurken, en düşük SOD aktivitesi Menengiç'te bulundu ( $\mathrm{p}<0.05)$. MDA seviyeleri Işgin'da en yüksek iken, en düşük MDA düzeyleri Çiriş Otu'nda bulundu $(\mathrm{p}<0.05)$.

Işgin, çiriş otu ve menegiç bitkilerinin antioksidan enzim aktiviteleri (SOD, CAT) Çizelge 1'de, MDA düzeyleri ise Şekil 1'de gösterilmiştir.

Çizelge 1. Işgın, menengiç ve çiriş otunda antioksidan enzim aktiviteleri (CAT ve SOD)

Table 1. Antioxidant enzyme activities (CAT and SOD) in Rheum Ribes L (Isgin), Pistacia Terebinthus (Menengiç), and Asphodelus Aestivus (Ciriş $\mathrm{Otu}$ )

\begin{tabular}{|c|c|c|c|c|}
\hline & $\begin{array}{l}\text { Rheum Ribes L } \\
\text { (Işgin)** }\end{array}$ & $\begin{array}{l}\text { Pistacia } \\
\text { (Menengiç) }\end{array}$ & Terebinthus & $\begin{array}{l}\text { Asphodelus Aestivus } \\
\text { (Çiriş Otu) }\end{array}$ \\
\hline CAT (Ü/mg protein) & $0.413 \pm 0.03^{*}$ & $0.01 \pm 0.008^{*}$ & & $0.065 \pm 0.007 *$ \\
\hline SOD (Ü/mg protein) & $0.34 \pm 0.01^{*}$ & $0.065 \pm 0.003^{*}$ & & $0.12 \pm 0.005^{*}$ \\
\hline
\end{tabular}

*Sonuçlar ortalama \pm standart hata olarak verildi.

**Işgın'da CAT ve SOD aktiviteleri diğer bitkilere kıyasla daha yüksek bulundu $(\mathrm{p}<0.05)$.

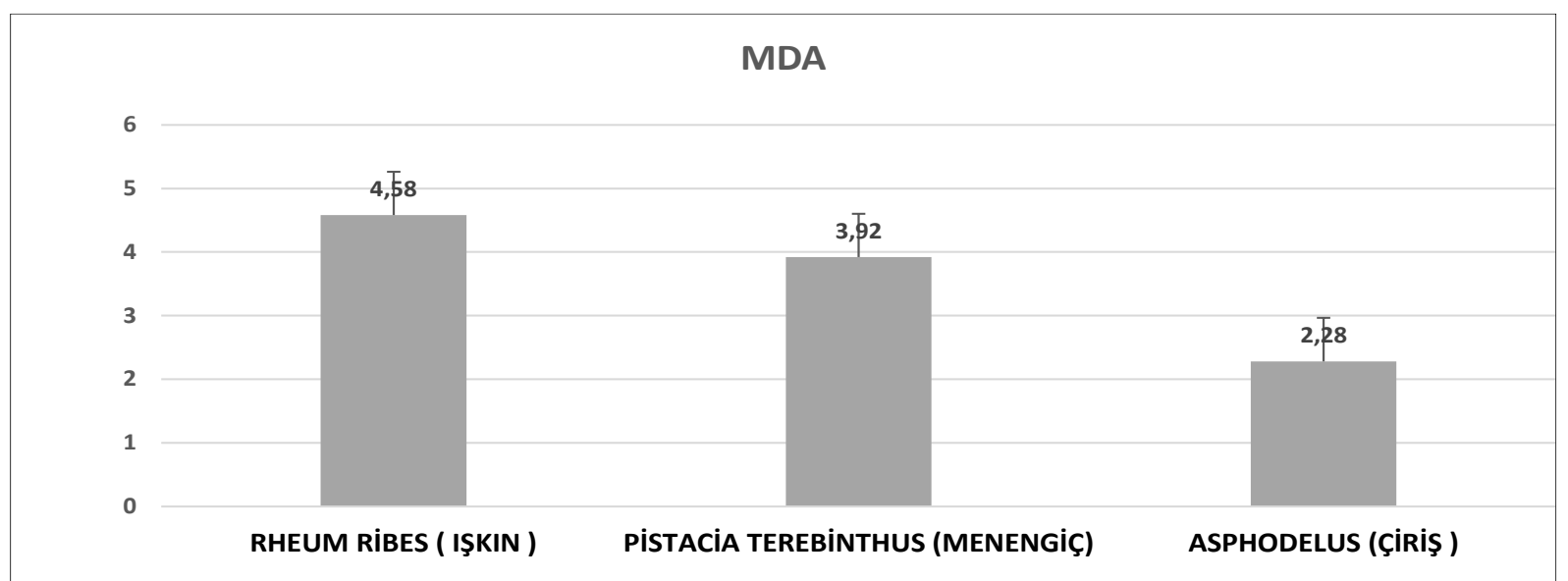

Şekil 1. Işgın (rheum ribes L.), Menengiç (pistacia terebinthus L) ve Çiriş Otu (asphodelus aestivus) MDA seviyelerinin karşılaştırılması.

Figure 1. Comparison of MDA levels of Işgin (rheum ribes L.), Menengiç (pistacia terebinthus L) and Çiriş Otu (asphodelus aestivus).

\section{TARTIŞMA ve SONUÇ}

Tarih boyunca tıbbi ve aromatik bitkiler hem tıbbi amaçlı olarak hem de gida maddesi olarak kullanılmış ve bu bitkilerin önemi giderek artmıştır. Günümüzde ise bu bitkilerin alternatif ve modern tıpta sıklıkla kullanıldığını görmekteyiz. Tıbbi ve aromatik etkiye sahip olan bitkilerin kök, yaprak, çiçek ve meyve gibi bölümlerinden elde edilen ekstrelerin, pek çok tıbbi ilacın ana maddesini oluşturduğu bilinmektedir.
İnsanların büyük çoğunluğu hastalıkların tedavisinde ilk olarak tıbbi bitkilere başvurmaktadır ve gelişmiş ülkelerde kullanılan tıbbi ilaçların \%25'inin ana maddesi bitkisel kökene sahiptir (Farnsworth, 1985).

Birçok hastalığın başlamasına öncülük eden oksidatif stres ve serbest radikallerin, canlı organizmalara olan zararlarını gidermek açısından, antioksidan yapıya sahip maddelerin radikal giderme aktivitelerinin bilinmesi büyük öneme sahiptir (Kurutas, 2015). Bu 
sayede sentetik antioksidanların yerini doğal antioksidanların alması açısından yoğun araştırmalar yapilmaktadir.

Tabata ve ark. (1994) göre, ışgin bitkisinin kökleri geleneksel olarak diyabet, hemoroit, ülser ve ishalin tedavisinde kullanılmakta ve aynı zamanda antelmentik ve balgam söktürücü aktivitelerinin olduğunu bildirmektedirler. Menengiç yapraklarının halk tarafından mide ve karın ağrılarının giderilmesinde, astım hastalığının tedavisinde ve iltihap gidermek için kaynatılarak içildiği bilinmektedir. Bununla birlikte yine ateş düşürücü, romatizma, öksürük, ayak terlemesi, yara, yanık ve idrar sökürücü olarak menengiç yapraklarından faydalanıldığı ifade edilmektedir. Çiriş otu hemoroid, romatizma, adet söktürücü, idrar söktürücü, saçkıran, süt artırıcı, egzama, sivilce ve çıbanların tedavisinde ilaç olarak kullanıldığı belirtilmektedir (Baytop, 1999).

Yapılan bu çalışmada, Işgın'ın en yüksek antioksidan enzim kapasitesine sahip olması; yüksek oranda fenolik içeriğinden kaynaklanabilir. Nitekim Ozbek ve ark. (2004) göre ışgın bitkisinin alloksan uygulanan farelerde hipoglisemik etkisi olduğu belirtilmiştir. Başka bir çalışmada ise Raafat ve ark. (2014) ışgının antioksidan etkiye sahip olduğunu, ışgın ekstraktının farelerde glukoz dengesini düzenlediğini ve diyabetik nefropatiye karşı önleyici etkiye sahip olduğunu belirtmişlerdir. Meral (2017) ise yapmış olduğu çalışmasında, ışgın bitkisinin antioksidan etkiye sahip olduğunu aynı zamanda yüksek miktarda fenolik bileşen içerdiğini belirtmektedir. Bu çalışma ise ışgın bitkisinin yüksek antioksidan enzim kapasitesine sahip olduğunu göstermiştir. Güzel ve ark. (2013) yapmış olduğu çalışmaya göre çiriş otu ekstreleri orta derecede serbest radikal önleyici etkiye sahip, doğal bir antioksidan kaynağıdır. Bu çalışmada ise ise diğer iki bitkiye nazaran çiriş otunda CAT aktivitesi ve MDA düzeyleri bakımından en düşük olduğu gözlendi.

Gülsoy ve ark. (2013) yapmış olduğu çalışmaya göre, menengiç bitkisinin kısımlarından sabit ve uçucu yağ elde edilmiş ve bu özelliklerinden dolayı ilaç ve kozmetik gibi alanlara katkı sağlayabilecek bir bitki türü olduğu saptanmış olup, araştırılmaya değer bir tür olarak görülmektedir. Bu çalışmada ise menengiç bitkisinin orta düzeyde antioksidan aktivitesi ve MDA düzeyine sahip olduğu saptandı. Çiriş otunun C vitamini açısından oldukça zengin bir yapıya sahip olmasıyla birlikte, glutatyon ve B3 vitamini miktarları açısından ise zengin yapıda olduğu tespit edilmiştir (Karataş ve ark., 2011). Bunun yanısıra, bu çalışmada bitkiler içinde en fazla antioksidan aktivitenin ışgında saptanması; çeşitli hastalıkların tedavisinde özellikle ışgının gövde kısımlarının tabletler halinde kullanılabileceğini düşündürmektedir.

Seçilen bitkilerin literatür taramalarında, in vitro olarak SOD, MDA ve CAT parametreleri açısından antioksidan aktiviteyi gösteren bir çalışmaya rastlanılmadı. Ülkemizin sahip olduğu bitki çeşitliliği göz önünde bulundurulunca bu çalışma, hem bu değere katkı sağlamış olacak hem de ileriki dönemlerde, radikal tutma özelliği olan başka bitki türleriyle ilgili yapılacak çalışmalara ışık tutacaktır.

\section{Araştırmacıların Katkı Oranı Beyan Özeti}

Yazarlar makaleye eşit oranda katkı sağlamış olduklarını beyan eder.

\section{Çıkar Çatışması Beyanı}

Makale yazarları aralarında herhangi bir çıkar çatışması olmadığını beyan ederler.

\section{KAYNAKLAR}

Baytop T 1984. Türkiye 'de Bitkiler ile Tedavi. İstanbul Üniversitesi Yayınları, İstanbul, 520sy.

Baytop T 1999. Türkiye'de Bitkiler ile Tedavi, Geçmişte ve Bugün. Nobel Tip Kitabevleri, İstanbul, 480sy.

Beutler E 1984. Red Cell Metabolism: A Manual of Biochemical Methods Third Edition. Grune and Stratton, New York, 11-12

Bursal E 2009. Kivi Meyvesinin (Actinidia Deliciosa) Antioksidan ve Antiradikal Aktivitelerinin Belirlenmesi, Karbonik Anhidraz Enziminin Saflaştırılması ve Karakterizasyonu. Atatürk Üniversitesi Fen Bilimleri Enstitüsü Kimya Ana Bilim Dalı, Doktora Tezi, 8sy.

Davis PH 1967. Flora of Turkey and The Aegean Islands, Edinburg Univ. Press. Aegean Islands, Vol.3, Edinburg Univ. Press, Edinburg, 268sy.

Delabar JM, Nicole A, Jacob Y, Sinet PM, Jeröme H, D'aurıol L, Meunier M, Rotıval M 1987. Cloning and Sequencing of a Rat CuZn Superoxide Dismutase cDNA: Correlation Between CuZn Superoxide Dismutase mRNA Level and Enzyme Activity in Rat and Mouse Tissues. European Journal of Biochemistry 166(1): 181-187.

Farnsworth NR, Akerele O, Bingel AS, Soejarto DD, Guo Z 1985. Medicinal Plants in Therapy. Bulletin of The World Health Organization 63 (6): 965-981.

Fridovich I 1995. Superoxide Radical and Superoxide Dismutases. Annual Review of Biochemistry 64(1): 97-112.

Gülsoy S, Özkan G, Özkan K, Genç M 2013. Effects of Ecological Factors on Some Physical and Physicochemical Fruit Characteristics of Turpentine Tree (Pistacia Terebinthus L. subsp. Palaestina (Boiss.) Engler). Turkish Journal of Forestry 14(1): 15-23.

Güzel E, Boğa R, Bursal E 2013. Çiriş Otunun (Asphodelus Aestivus) Antioksidan Aktivitesinin Belirlenmesi. Muş Alparslan Üniversitesi Fen Bilimleri Dergisi 1 (1): 17-25. 
Karataş F, Bektaş İ, Birişik A, Aydın Z, Kurtul A 2011. Çiriş Otu'nda (Asphodelus Aestivus L.) Suda Çözünen Bazı Bileşiklerin Araştırılması. Süleyman Demirel Üniversitesi Fen Edebiyat Fakültesi Fen Dergisi 6(1): 35-39.

Kurutas EB 2015. The Importance of Antioxidants Which Play The Role in Cellular Response Against Oxidative/Nitrosative Stress: Current State. Nutrition Journal 15(1): 1-22.

Lowry OH, Rosebrough NJ, Farr AL, Randall RJ 1951. Protein Measurement With The Folin Phenol Reagent. Journal of Biological Chemistry 193(1): 265-275.

Meral R 2017. Farklı Sicaklık Derecelerinin Uşkun Bitkisinin Antioksidan Aktivitesi ve Fenolik Profili Üzerine Etkisi. Yüzüncü Yıl Üniversitesi Tarım Bilimleri Dergisi 27(1): 88-94.

Ohkawa H, Ohishi N, Yagi K 1979. Assay For Lipid Peroxides in Animal Tissues By Thiobarbituric Acid Reaction. Analytical Biochemistry 95(2): 351-358.

Ozbek H, Ceylan E, Kara M, Ozgokce F, Koyuncu M 2004. Hypoglycemic Effect of Rheum Ribes Roots in
Alloxan Induced Diabetic And Normal Mice. Scandınavian Journal of Laboratory Anımal Science Vol.31: 113-115.

Raafat K, Aboul-Ela M, El-Lakany A 2014. AlloxanInduced Diabetic Thermal Hyperalgesia, Prophylaxis and Phytotherapeutic Effects of Rheum Ribes L. in Mouse Model. Archives of Pharmacal Research 1-10.

Sen S, Chakraborty R, Sridhar C, Reddy YSR, De B 2010. Free Radicals, Antioxidants, Diseases and Phytomedicines: Current Status and Future Prospect. International Journal of Pharmaceutical Sciences Review and Research 3(1): 91-100.

Shinde A, Ganu J, Naik P 2012. Effect of Free Radicals \& Antioxidants on Oxidative Stress: A Review. Journal of Dental and Allied Sciences 1(2): 63.

Tabata M, Sezik E, Honda G, Yesilada E, Fuki H, Goto K, Ikeshiro Y 1994. Traditional Medicine in Turkey III. Folk Medicine in East Anatolia, Van and Bitlis Provinces. International Journal of Pharmacognosy 32(1): 3-12. 